\title{
1 Impact of Daily Weather on COVID-19 outbreak in India
}

2 Amitesh Gupta $^{1 *}$, Biswajeet Pradhan ${ }^{2,3}$

3 Email: amitesh13gupta14@gmail.com, Biswajeet.Pradhan@uts.edu.au

$4 \quad{ }^{1}$ Remote Sensing and GIS Department, JIS University, Agarpara, Kolkata, India.

$5 \quad{ }^{2}$ Centre for Advanced Modelling and Geospatial Information Systems (CAMGIS), Faculty of

6 Engineering \& IT, University of Technology Sydney, Australia

$7 \quad{ }^{3}$ Department of Energy and Mineral Resources Engineering, Sejong University, Choongmu-

8 gwan, 209 Neungdong-ro, Gwangjin-gu, Seoul 05006, Korea

\section{*For Correspondence}

11 Email: amitesh13gupta14@gmail.com

12 Mobile: +917278142538 
medRxiv preprint doi: https://doi.org/10.1101/2020.06.15.20131490; this version posted June 17, 2020. The copyright holder for this preprint (which was not certified by peer review) is the author/funder, who has granted medRxiv a license to display the preprint in perpetuity.

All rights reserved. No reuse allowed without permission.

\section{Abstract}

22 The COVID-19 pandemic has outspread obstreperously in India. As of June 04, 2020, more

23 than 2 lakh cases have been confirmed with a death rate of $2.81 \%$. It has been noticed that,

24 out of each 1000 tests, 53 result positively infected. In order to investigate the impact of 25 weather conditions on daily transmission occurring in India, daily data of Maximum $\left(T_{\operatorname{Max}}\right)$,

26 Minimum $\left(T_{M i n}\right)$, Mean $\left(T_{\text {Mean }}\right)$ and Dew Point Temperature $\left(T_{D e w}\right)$, Diurnal Temperature 27 range $\left(T_{\text {Range }}\right)$, Average Relative Humidity, Range in Relative Humidity, and Wind Speed 28 (WS) over 9 most affected cities are analysed in several time frames: weather of that day, 7, $10,12,14,16$ days before transmission. Spearman's rank correlation (r) shows significant but

30 low correlation with most of the weather parameters, however, comparatively better association exists on 14 days lag. Diurnal range in Temperature and Relative Humidity shows non-significant correlation. Analysis shows, COVID-19 cases likely to be increased with increasing air temperature, however role of humidity is not clear. Among weather parameters, Minimum Temperature was relatively better correlate than other. $80 \%$ of the total confirmed cases were registered when $T_{M a x}, T_{M e a n}, T_{M i n}, T_{R a n g e}, T_{D e w}$, and $W S$ on 12-16 days ago vary within a range of $33.6-41.3^{\circ} \mathrm{C}, 29.8-36.5^{\circ} \mathrm{C}, 24.8-30.4^{\circ} \mathrm{C}, 7.5-15.2^{\circ} \mathrm{C}, 18.7-23.6^{\circ} \mathrm{C}$, and 4.2-5.75 m/s respectively, hence, it gives an idea of susceptible weather conditions for such transmission in India. Using Support Vector Machine based regression, the daily cases are profoundly estimated with more than $80 \%$ accuracy, which indicate that coronavirus transmission can't be well linearly correlated with any single weather parameters, rather multivariate non-linear approach must be employed. Accounting lag of 12-16 days, the association found to be excellent, thus depict that there is an incubation period of $14 \pm 02$

43 days for coronavirus transmission in Indian scenario.

\section{Keywords:}


medRxiv preprint doi: https://doi.org/10.1101/2020.06.15.20131490; this version posted June 17, 2020. The copyright holder for this preprint (which was not certified by peer review) is the author/funder, who has granted medRxiv a license to display the preprint in perpetuity.

All rights reserved. No reuse allowed without permission.

45 COVID-19; pandemic; weather; India

\section{Introduction}

47 In human history, it is apparent that pathogens have caused devastating consequences in

48 social wellbeing and economy (Briz-Redón and Serrano-Aroca, 2020). The recent novel

49 coronavirus disease (COVID-19) is one of the prominent example of such a disastrous event

50 that has grasped the world. The earliest outbreak of COVID-19 caused by Severe Acute

51 Respiratory Syndrome CoronaVirus-2 (SARS-CoV-2) happened in Wuhan, Hubei Province,

52 China during the late December, 2019, (Guan et al., 2020b; Wu and McGoogan, 2020; Zhu et

53 al., 2020; Zu et al., 2020). Because of human-to-human transmissibility of the virus (Wang et

54 al., 2020a; 2020b), the circumstances become progressively unpredictable and vulnerable in

55 terms of transmission of this disease. Considering the rapid turnaround, the World Health

56 Organization (WHO) declared an international public health emergency on January 30, 2020,

57 and later on March 11, 2020, WHO declared this disease as global pandemic due to speedy

58 blowout of infections. Till June 04, 2020, a total of 6,709,724 cases have been affirmed with

$595.85 \%$ deaths worldwide (https://www.worldometers.info/coronavirus). Despite the fact India

60 has registered its first case on January 29, 2020, the outbreak occurred March 2, 2020

61 onwards and as of June 04, 2020, a total of 226,722 cases have been confirmed; however, the

62 death rate $(2.81 \%)$ is quite lower than the worldwide situation.

63 Clinical investigations on COVID-19 identified respiratory droplets as the most common

64 agent of this infection (Ge et al., 2013; Huang et al., 2020). The reported symptoms are also

65 quite analogous to the other coronavirus diseases such as MERS and SARS, e.g. moderate to

66 high fever with dry cough, and difficulty in breathing attributable to respiratory disorder in

67 early stage, while it causes kidney failure, pneumonia in severe phase (Holshue et al., 2020;

68 Perlman, 2020; Tan et al., 2005; Wang et al., 2020c). 
69 Environmental factors, such as daily weather and long term climatic conditions may affect

70 the epidemiological dynamics of this type of infectious disease (Dalziel et al., 2018; Yuan et

71 al., 2006). Daily air temperature and relative humidity may impact on the transmissions of

72 coronavirus by affecting the persistence of the viral infections within its transmission routes

73 (Casanova et al., 2010). A few studies accounting climate and weather conditions found that

74 these factors considerably affect the spatial distribution along with its incubation period

75 (Bedford et al., 2015; Lemaitre et al., 2019; Sooryanarain and Elankumaran, 2015). At the

76 earliest, Bull (1980) reported that the mortality rate of pneumonia is profoundly associated

77 with the changes in weather condition. Studies have revealed that among different climatic

78 variables the air temperature affects the influenza epidemics mostly in tropical regions

79 (Tamerius et al., 2013) whereas the mid-latitudinal temperate regions experience the

80 influenza diseases epidemics mostly during winter months (Bedford et al., 2015;

81 Sooryanarain and Elankumaran, 2015). Nevertheless, the response to weather pattern on

82 COVID-19 transmission found quite debatable, since, the studies carried out in different

83 countries in the world suggested an existing correlation between weather and COVID-19

84 pandemic likewise that it occurs with other influenza infections (Ficetola and Rubolini, 2020;

85 Liu et al., 2020; Ma et al., 2020; Oliveiros et al., 2020; Qi et al., 2020; Tosepu et al., 2020).

86 Contradictorily, few studies have reported that meteorological observations are not correlated

87 with outbreak pattern (Jamil et al., 2020; Mollalo et al., 2020; Shi et al., 2020; Xie and Zhu,

88 2020). Studies carried out by Wang et al., 2020a; Wang et al., 2020b suggested that the

89 spread of disease supposed to be decreased with an increase in temperature. Gupta et al.

90 (2020a) also predicted lowering of transmission in warmer conditions in India. However, in

91 view of the long term climate record, Gupta et al., 2020b found, comparatively hot areas in

92 India are possibly going to be more affected by this disease. Besides, the incubation period of

93 COVID-19 also may vary spatially. The WHO reported an incubation period of 2-10 days for 
medRxiv preprint doi: https://doi.org/10.1101/2020.06.15.20131490; this version posted June 17, 2020. The copyright holder for this preprint

94 COVID-19 based on worldwide observation (Novel Coronavirus(2019-nCoV) Situation

95 Report - 7, 2020) while the National Health Commission in China had initially estimated an

96 incubation period of 10-14 days for China (https://www.aljazeera.com/news/2020/01/chinas-

97 national-health-commission-news-conference-coronavirus-200126105935024.html) and the

98 Centres for Disease Control and Prevention in United States of America estimate this

99 incubation period of 2-14 days (https://www.cdc.gov/coronavirus/2019-ncov/symptoms-

100 testing/symptoms.html). On other hand, Bai et al., 2020; Guan et al., 2020a reported 101 incubation period of around 20days. Since no such study has investigated the impact of daily 102 weather on COVID-19 transmission in Indian context as well as the incubation period of this 103 disease in India is not mentioned anywhere to date, there is a need of comprehensive study 104 for Indian scenario. Thus, the present study is aimed to understand the trends, abrupt changes 105 and influence of daily weather conditions in COVID-19 transmission in India. We have also 106 investigated the incubation period of this disease based on five timeframes, specifically on 107 the day of the case, within $7,10,12,14$, and 16 days of the case.

India, the largest country in South Asia, extended from $6^{\circ} \mathrm{N}$ to $38^{\circ} \mathrm{N}$ and $68^{\circ} \mathrm{E}$ to $98^{\circ} \mathrm{E}$, comprising a land area of 3.287 million sq. $\mathrm{km}$. with a total population of more than 1.2 billion (Census, 2011). The data of daily COVID-19 cases were collected from the official website of the Ministry of Health of India (https://www.mohfw.gov.in). Among 725 districts in India, more than $85 \%$ has reported multiple confirmed cases. Several studies have reported that the disease spread at a higher rate in the cities where population is very high (Ahmadi et al., 2020; Bonasera and Zhang, 2020; Casanova et al., 2010; Kang et al., 2020; Rocklöv and Sjödin, 2020). Thus, among 53 'million cities' (where the total population is more than one million) in India, 9 cities have been selected for this study (Fig. 1), from where more than 
medRxiv preprint doi: https://doi.org/10.1101/2020.06.15.20131490; this version posted June 17, 2020. The copyright holder for this preprint

$79 \%$ of total cases in India have been reported till June 4, 2020. The trend of confirmed cases over those cities along with comparison of trend of daily transmission in entire country is highly increasing (Fig. 2). The weather data were collected from https://www.wunderground.com. Fig. 3 shows the prevailing weather conditions in terms of Maximum, Minimum and Mean Temperature, Diurnal Range in Temperature, Dew Point Temperature, Average Relative Humidity, Diurnal Range in Relative Humidity and Wind Speed in those cities. It exhibits that there were variations in weather conditions in different cities, hence, this study will signify how spatially varying weather conditions influence the pattern of COVID-19 transmission in India.

\subsection{Spearman's correlation test}

Spearman's rank correlation coefficient $\left(r_{s}\right)$ is implemented to define the association between a number of daily new cases and weather parameters. It summarizes how well the association between daily transmission and weather parameters can be demarcated. The coefficient can be calculated via the following equation -

$$
r_{s}=1-6 \frac{\sum d_{i}^{2}}{n\left(n^{2}-1\right)}
$$

where, $n$ represents the number of alternatives, and $d_{i}$ is the difference between the ranks of two parameters.

\subsection{Support Vector Machine}

Support Vector Machine (SVM) is an extensively utilized machine learning technique. It is performed on the basis of statistical auto-adaptation and structural risk minimization principle (Tien Bui et al., 2012). By creating hyper-plane, the nonlinearity in the input dataset is reshaped into the linearity (Jebur et al., 2014). Here, kernel function is the key factor behind this data transformation. Using the assigned training dataset, SVM put the original input into 
a higher dimensional feature space, then finds the supreme fringe of separation among the observations and constructs a hyper-plane at the centre of that extreme margin (Marjanović et al., 2011). Support vectors are nothing but the nearest training points to the produced hyper plane. Thus, this model adapt itself by input observations and create hyper-plane and identify the support vectors and thereafter acted on the input variables of testing dataset to estimate the predicted variable. Further insights about the mathematical computations and procedures work in SVM can be found in several literature such as Pradhan, 2013; Tehrany et al., 2015, 2014; Tien Bui et al., 2012. However, the accuracy of estimation depends on the kernel type selected during the training of the model (Yao et al., 2008). The Radial basis function (RBF) kernel produce preferred exactness than linear, polynomial and sigmoid kernels due to its higher capability in interpolation (Song et al., 2011).

Early observation by Gupta et al. (2020c) noted that transmission in India is likely to be higher over those area which are located in lower altitudes and having higher population. Thus, we also incorporate elevation and population of those selected cities along with the daily weather and estimate the log-transformed value of daily COVID-19 cases (Eq. 10).

$$
\ln (N C)=T_{\text {Max }}+T_{\text {Min }}+T_{\text {Mean }}+T_{\text {range }}+T_{\text {Dew }}+H_{\text {Avg }}+H_{\text {range }}+W S+\text { Ele }+ \text { Pop }
$$

where, $N C$ is the number of New Confirmed Case, $T_{\text {Max }}$ is Maximum Air Temperature $\left({ }^{\circ} \mathrm{C}\right)$, $T_{\text {Min }}$ is Minimum Air Temperature $\left({ }^{\circ} \mathrm{C}\right), T_{\text {Mean }}$ is Mean Air Temperature $\left({ }^{\circ} \mathrm{C}\right), T_{\text {range }}$ is Temperature Range $\left({ }^{\circ} \mathrm{C}\right), T_{\text {Dew }}$ is Dew point Temperature $\left({ }^{\circ} \mathrm{C}\right), H_{A v g}$ is Average Relative Humidity (\%), $H_{A v g}$ is Range of Relative Humidity (\%), WS is Wind Speed, Ele is Elevation (m), Pop is total Population. 
medRxiv preprint doi: https://doi.org/10.1101/2020.06.15.20131490; this version posted June 17, 2020. The copyright holder for this preprint

$70 \%$ of the total observation was used as training dataset and rest used for testing. The

accuracy of estimation was evaluated in terms of $\mathrm{R}^{2}$, Root Mean Square Error (RMSE) and

Mean Bias (MB).

\section{Results and discussion}

The Spearman's correlation analysis (Table 1) shows that there were mostly significant but considerably low correlation lies between the number of daily new case and weather condition. Among weather parameters, only $T_{\text {range }}$ and $H_{\text {range }}$ are negatively correlated with the daily transmission, however, correlation for $T_{\text {range }}$ is non-significant in all time span. Hence, the diurnal range of temperature is not significantly associated with COVID-19 transmission in India. $H_{\text {avg }}$ is significant on the day of transmission up to 10 days ago of transmission, while $H_{\text {range }}$ is significant 12-16 days ago of transmission; it suggest that the role of humidity is quite complex and needed to be investigated further in depth. On other hand, the analysis indicate that the $T_{\max }, T_{\min }, T_{\text {mean }}, T_{\text {Dew }}$ on the day of the transmission has the lowest correlation and it improves at its best with a time lag of 14 days. In other words, the maximum, minimum, mean and dew point temperature on 14 days ago of transmission is closely related with a number of infections. Interestingly, $T_{\min }$ is found better related than $T_{\text {mean }} T_{\max } T_{D e w}$. Therefore, places with higher minimum temperature are more susceptible for COVID-19 transmission in India. WS also found to be positively correlated with daily transmission, which may infer that virus might be able to transmigrate with high wind. Since, most of the weather parameters including WS, are better correlate with the daily confirmed cases with a time lag of 14 days, it indicate an approximate incubation period of around 14 days for this disease in the Indian scenario.

Fig. 4 shows the validation of estimated daily confirmed cases for all time spans using nonlinear multivariate Support Vector Regression Model with RBF kernel. The model 
medRxiv preprint doi: https://doi.org/10.1101/2020.06.15.20131490; this version posted June 17, 2020. The copyright holder for this preprint

performance in terms of $\mathrm{R}^{2}, \mathrm{RMSE}, \mathrm{MB}$ are represented in Table 2. It depicts that SVM based regression model is very efficient to establish the complex relationship among different weather parameters with the daily transmission of COVID-19, however, it exhibits an underestimation for very high values (>1200 cases). Hence, it make us understood that any single weather parameter is not enough to linearly correlate the daily transmission, rather than that, the non-linear multivariate approach is efficient to estimate the daily transmission in India with high accuracy. Correlation analysis has evidently stipulated a relatively higher degree of association for daily new cases with most of the parameters only when the time lag of 14 days is taken in to consideration. The SVM based regression model also performs remarkably well with a time lag of more than 12 days. These together suggest a conspicuous incubation period of 12-16 (14 \pm 02$)$ days for this transmission in India. In order to better understand the influence of varying weather conditions, the response curve of significant parameters to cumulative confirmed cases was framed (Fig. 5), which reveal that there is an acute range in weather parameters for which the transmission is highly susceptible. $80 \%$ of the total confirmed cases were registered when $T_{M a x}, T_{M e a n}, T_{M i n}, T_{R a n g e}, T_{D e w}$, and WS on 1216 days ago vary within a range of $33.6-41.3^{\circ} \mathrm{C}, 29.8-36.5^{\circ} \mathrm{C}, 24.8-30.4^{\circ} \mathrm{C}, 7.5-15.2^{\circ} \mathrm{C}$, 18.7-23.6 $6^{\circ}$, and 4.2-5.75 m/s respectively. Hence, it gives an idea of susceptible weather conditions for such transmission in India. In other words, the areas experiencing such weather pattern in India must have been affected by this disease.

\section{Conclusion}

Unlike most of the studies, the present study investigated the impact of daily maximum, minimum, mean, and dew point temperature, temperature range, average humidity, humidity range and wind speed on that day, as well as within $7,10,12,14$, and 16 days of the confirmed cases of COVID-19 in the Indian context. The analysis revealed that the count of confirmed cases significantly correlated with a certain range of weather conditions. Thus, 
213 instead of linear correlation, SVM based regression approach efficaciously resolve this

214 complex association and able to estimate daily cases of transmission using the weather inputs.

215 However, the positive correlation between daily transmission and air temperature as well as

216 wind speed designates that the daily transmission in highly populated areas in India has been

217 responsively increased during current summer days. A prominent incubation period of $14 \pm$

21802 days has also been identified, which was a little higher than what WHO had prescribed 219 early in March. Therefore, in the prevailing weather conditions in India, the SARS-CoV-2 220 can be disseminated into the surrounding environment for around two weeks after being 221 grieved from any other contaminant. This study had faced several limitations since many 222 other major affected cities were not able to incorporate due to lack of data availability. 223 Besides, the count of immigrants from abroad or other cities and have been quarantined were 224 not available; these might can enhance the exactitude of the current analysis.

\section{CRediT authorship contribution statement}

227 Amitesh Gupta: Conceptualization, Methodology, Investigation, Visualization, Writing 228 original draft. Biswajeet Pradhan: Writing - review and editing, Supervision.

230 Acknowledgement

231 This research had not any funding support. Mr. Sumit Das is highly acknowledged for his 232 continuous supports and substantial editing to improve the quality of paper and proof reading. 
medRxiv preprint doi: https://doi.org/10.1101/2020.06.15.20131490; this version posted June 17, 2020. The copyright holder for this preprint (which was not certified by peer review) is the author/funder, who has granted medRxiv a license to display the preprint in perpetuity.

\section{References}

238 Ahmad, I., Tang, D., Wang, T., Wang, M., Wagan, B., 2015. Precipitation Trends over Time Using Mann-Kendall and Spearman’s rho Tests in Swat River Basin, Pakistan. Advances in Meteorology 2015, 1-15. https://doi.org/10.1155/2015/431860

Ahmadi, M., Sharifi, A., Dorosti, S., Jafarzadeh Ghoushchi, S., Ghanbari, N., 2020. Investigation of effective climatology parameters on COVID-19 outbreak in Iran. Science of The Total Environment 729, 138705. 
medRxiv preprint doi: https://doi.org/10.1101/2020.06.15.20131490; this version posted June 17, 2020. The copyright holder for this preprint (which was not certified by peer review) is the author/funder, who has granted medRxiv a license to display the preprint in perpetuity.

All rights reserved. No reuse allowed without permission.

Casanova, L.M., Jeon, S., Rutala, W.A., Weber, D.J., Sobsey, M.D., 2010. Effects of air temperature and relative humidity on coronavirus survival on surfaces. Appl. Environ. Microbiol. 76, 2712-2717. https://doi.org/10.1128/AEM.02291-09

Collaud Coen, M., Andrews, E., Asmi, A., Baltensperger, U., Bukowiecki, N., Day, D., Fiebig, M., Fjaeraa, A.M., Flentje, H., Hyvärinen, A., Jefferson, A., Jennings, S.G., Kouvarakis, G., Lihavainen, H., Lund Myhre, C., Malm, W.C., Mihapopoulos, N., Molenar, J.V., O\&amp;apos;Dowd, C., Ogren, J.A., Schichtel, B.A., Sheridan, P., Virkkula, A., Weingartner, E., Weller, R., Laj, P., 2013. Aerosol decadal trends - Part 1: In-situ optical measurements at GAW and IMPROVE stations. Atmos. Chem. Phys. 13, 869-894. https://doi.org/10.5194/acp-13-869-2013

Dalziel, B.D., Kissler, S., Gog, J.R., Viboud, C., Bjørnstad, O.N., Metcalf, C.J.E., Grenfell, B.T., 2018. Urbanization and humidity shape the intensity of influenza epidemics in U.S. cities. Science 362, 75-79. https://doi.org/10.1126/science.aat6030

Ficetola, G.F., Rubolini, D., 2020. Climate affects global patterns of COVID-19 early outbreak dynamics. medRxiv 2020.03.23.20040501. https://doi.org/10.1101/2020.03.23.20040501

Gao, P., Mu, X.-M., Wang, F., Li, R., 2011. Changes in streamflow and sediment discharge and the response to human activities in the middle reaches of the Yellow River. Hydrology and Earth System Sciences 15, 1-10. https://doi.org/10.5194/hess-15-12011

Gatto, M., Bertuzzo, E., Mari, L., Miccoli, S., Carraro, L., Casagrandi, R., Rinaldo, A., 2020. Spread and dynamics of the COVID-19 epidemic in Italy: Effects of emergency containment measures. PNAS 117, 10484-10491. https://doi.org/10.1073/pnas.2004978117 
medRxiv preprint doi: https://doi.org/10.1101/2020.06.15.20131490; this version posted June 17, 2020. The copyright holder for this preprint (which was not certified by peer review) is the author/funder, who has granted medRxiv a license to display the preprint in perpetuity.

All rights reserved. No reuse allowed without permission.

Ge, X.-Y., Li, J.-L., Yang, X.-L., Chmura, A.A., Zhu, G., Epstein, J.H., Mazet, J.K., Hu, B., Zhang, W., Peng, C., Zhang, Y.-J., Luo, C.-M., Tan, B., Wang, N., Zhu, Y., Crameri, G., Zhang, S.-Y., Wang, L.-F., Daszak, P., Shi, Z.-L., 2013. Isolation and characterization of a bat SARS-like coronavirus that uses the ACE2 receptor. Nature 503, 535-538. https://doi.org/10.1038/nature12711

Gocic, M., Trajkovic, S., 2013. Analysis of changes in meteorological variables using MannKendall and Sen's slope estimator statistical tests in Serbia. Global and Planetary Change 100, 172-182. https://doi.org/10.1016/j.gloplacha.2012.10.014

Guan, W., Ni, Z., Hu, Yu, Liang, W., Ou, C., He, J., Liu, L., Shan, H., Lei, C., Hui, D.S., Du, B., Li, L., Zeng, G., Yuen, K.-Y., Chen, R., Tang, C., Wang, T., Chen, P., Xiang, J., Li, S., Wang, Jin-lin, Liang, Z., Peng, Y., Wei, L., Liu, Y., Hu, Ya-hua, Peng, P., Wang, Jian-ming, Liu, J., Chen, Z., Li, G., Zheng, Z., Qiu, S., Luo, J., Ye, C., Zhu, S., Zhong, N., 2020a. Clinical characteristics of 2019 novel coronavirus infection in China. medRxiv 2020.02.06.20020974. https://doi.org/10.1101/2020.02.06.20020974

Guan, W., Ni, Z., Hu, Yu, Liang, W., Ou, C., He, J., Liu, L., Shan, H., Lei, C., Hui, D.S.C., Du, B., Li, L., Zeng, G., Yuen, K.-Y., Chen, R., Tang, C., Wang, T., Chen, P., Xiang, J., Li, S., Wang, Jin-lin, Liang, Z., Peng, Y., Wei, L., Liu, Y., Hu, Ya-hua, Peng, P., Wang, Jian-ming, Liu, J., Chen, Z., Li, G., Zheng, Z., Qiu, S., Luo, J., Ye, C., Zhu, S., Zhong, N., 2020b. Clinical Characteristics of Coronavirus Disease 2019 in China. N Engl J Med 382, 1708-1720. https://doi.org/10.1056/NEJMoa2002032

Güçlü, Y.S., 2018. Multiple Şen-innovative trend analyses and partial Mann-Kendall test. Journal of Hydrology 566, 685-704. https://doi.org/10.1016/j.jhydrol.2018.09.034

Gupta, A., Banerjee, S., Das, S., 2020b. Significance of geographical factors (climatic, topographic and social) to the COVID-19 outbreak in India. OSF Preprints. https://doi.org/10.31219/osf.io/9gqpm 
medRxiv preprint doi: https://doi.org/10.1101/2020.06.15.20131490; this version posted June 17, 2020. The copyright holder for this preprint (which was not certified by peer review) is the author/funder, who has granted medRxiv a license to display the preprint in perpetuity.

All rights reserved. No reuse allowed without permission.

Gupta, A., Banerjee, S., Das, S., 2020c. Significance of geographical factors to the COVID19 outbreak in India. Modeling Earth Systems and Environment. https://doi.org/10.1007/s40808-020-00838-2

Gupta, S., Raghuwanshi, G.S., Chanda, A., 2020a. Effect of weather on COVID-19 spread in the US: A prediction model for India in 2020. Science of The Total Environment 728, 138860. https://doi.org/10.1016/j.scitotenv.2020.138860

Hänsel, S., Medeiros, D.M., Matschullat, J., Petta, R.A., de Mendonça Silva, I., 2016. Assessing Homogeneity and Climate Variability of Temperature and Precipitation Series in the Capitals of North-Eastern Brazil. Front. Earth Sci. 4. https://doi.org/10.3389/feart.2016.00029

Holshue, M.L., DeBolt, C., Lindquist, S., Lofy, K.H., Wiesman, J., Bruce, H., Spitters, C., Ericson, K., Wilkerson, S., Tural, A., Diaz, G., Cohn, A., Fox, L., Patel, A., Gerber, S.I., Kim, L., Tong, S., Lu, X., Lindstrom, S., Pallansch, M.A., Weldon, W.C., Biggs, H.M., Uyeki, T.M., Pillai, S.K., 2020. First Case of 2019 Novel Coronavirus in the United States. New England Journal of Medicine 382, 929-936. https://doi.org/10.1056/NEJMoa2001191

Huang, C., Wang, Y., Li, X., Ren, L., Zhao, J., Hu, Y., Zhang, L., Fan, G., Xu, J., Gu, X., Cheng, Z., Yu, T., Xia, J., Wei, Y., Wu, W., Xie, X., Yin, W., Li, H., Liu, M., Xiao, Y., Gao, H., Guo, L., Xie, J., Wang, G., Jiang, R., Gao, Z., Jin, Q., Wang, J., Cao, B., 2020. Clinical features of patients infected with 2019 novel coronavirus in Wuhan, China. The Lancet 395, 497-506. https://doi.org/10.1016/S0140-6736(20)30183-5

Jaiswal, R.K., Lohani, A.K., Tiwari, H.L., 2015. Statistical Analysis for Change Detection and Trend Assessment in Climatological Parameters. Environ. Process. 2, 729-749. https://doi.org/10.1007/s40710-015-0105-3 
medRxiv preprint doi: https://doi.org/10.1101/2020.06.15.20131490; this version posted June 17, 2020. The copyright holder for this preprint (which was not certified by peer review) is the author/funder, who has granted medRxiv a license to display the preprint in perpetuity.

All rights reserved. No reuse allowed without permission.

Jamil, T., Alam, I.S., Gojobori, T., Duarte, C., 2020. No Evidence for TemperatureDependence of the COVID-19 Epidemic. medRxiv 2020.03.29.20046706. https://doi.org/10.1101/2020.03.29.20046706

Jebur, M.N., Pradhan, B., Tehrany, M.S., 2014. Manifestation of LiDAR-Derived Parameters in the Spatial Prediction of Landslides Using Novel Ensemble Evidential Belief Functions and Support Vector Machine Models in GIS. IEEE J. Sel. Top. Appl. Earth Observations Remote Sensing 8, 674-690. https://doi.org/10.1109/JSTARS.2014.2341276

Kang, D., Choi, H., Kim, J.-H., Choi, J., 2020. Spatial epidemic dynamics of the COVID-19 outbreak in China. International Journal of Infectious Diseases 94, 96-102. https://doi.org/10.1016/j.ijid.2020.03.076

Kendall, M.G., 1975. Rank Correlation Methods. London, UK.

Koo, J.R., Cook, A.R., Park, M., Sun, Y., Sun, H., Lim, J.T., Tam, C., Dickens, B.L., 2020. Interventions to mitigate early spread of SARS-CoV-2 in Singapore: a modelling study. The Lancet Infectious Diseases 20, 678-688. https://doi.org/10.1016/S14733099(20)30162-6

Lemaitre, J., Pasetto, D., Perez-Saez, J., Sciarra, C., Wamala, J.F., Rinaldo, A., 2019. Rainfall as a driver of epidemic cholera: Comparative model assessments of the effect of intraseasonal precipitation events. Acta Tropica 190, 235-243. https://doi.org/10.1016/j.actatropica.2018.11.013

Leung, K., Wu, J.T., Liu, D., Leung, G.M., 2020. First-wave COVID-19 transmissibility and severity in China outside Hubei after control measures, and second-wave scenario planning: a modelling impact assessment. The Lancet 395, 1382-1393. https://doi.org/10.1016/S0140-6736(20)30746-7 
medRxiv preprint doi: https://doi.org/10.1101/2020.06.15.20131490; this version posted June 17, 2020. The copyright holder for this preprint (which was not certified by peer review) is the author/funder, who has granted medRxiv a license to display the preprint in perpetuity.

Liu, J., Zhou, J., Yao, J., Zhang, X., Li, L., Xu, X., He, X., Wang, B., Fu, S., Niu, T., Yan, J., Shi, Y., Ren, X., Niu, J., Zhu, W., Li, S., Luo, B., Zhang, K., 2020. Impact of meteorological factors on the COVID-19 transmission: A multi-city study in China. Science of The Total Environment 726, 138513. https://doi.org/10.1016/j.scitotenv.2020.138513

Ma, Y., Zhao, Y., Liu, J., He, X., Wang, B., Fu, S., Yan, J., Niu, J., Zhou, J., Luo, B., 2020. Effects of temperature variation and humidity on the death of COVID-19 in Wuhan, China. Science of The Total Environment 724, 138226. https://doi.org/10.1016/j.scitotenv.2020.138226

Mallakpour, I., Villarini, G., 2016. A simulation study to examine the sensitivity of the Pettitt test to detect abrupt changes in mean. Hydrological Sciences Journal 61, 245-254. https://doi.org/10.1080/02626667.2015.1008482

Mann, H.B., 1945. Nonparametric Tests Against Trend. Econometrica 13, 245. https://doi.org/10.2307/1907187

Marjanović, M., Kovačević, M., Bajat, B., Voženílek, V., 2011. Landslide susceptibility assessment using SVM machine learning algorithm. Engineering Geology 123, 225234. https://doi.org/10.1016/j.enggeo.2011.09.006

McBryde, E.S., Gibson, G., Pettitt, A.N., Zhang, Y., Zhao, B., McElwain, D.L.S., 2006. Bayesian modelling of an epidemic of severe acute respiratory syndrome. Bull. Math. Biol. 68, 889-917. https://doi.org/10.1007/s11538-005-9005-4

Mollalo, A., Vahedi, B., Rivera, K.M., 2020. GIS-based spatial modeling of COVID-19 incidence rate in the continental United States. Science of The Total Environment 728, 138884. https://doi.org/10.1016/j.scitotenv.2020.138884

Novel Coronavirus(2019-nCoV) Situation Report - 7, 2020. . World Health Organization. 
medRxiv preprint doi: https://doi.org/10.1101/2020.06.15.20131490; this version posted June 17, 2020. The copyright holder for this preprint (which was not certified by peer review) is the author/funder, who has granted medRxiv a license to display the preprint in perpetuity.

All rights reserved. No reuse allowed without permission.

Oliveiros, B., Caramelo, L., Ferreira, N.C., Caramelo, F., 2020. Role of temperature and humidity in the modulation of the doubling time of COVID-19 cases. medRxiv 2020.03.05.20031872. https://doi.org/10.1101/2020.03.05.20031872

Perlman, S., 2020. Another Decade, Another Coronavirus. New England Journal of Medicine 382, 760-762. https://doi.org/10.1056/NEJMe2001126

Pettitt, A.N., 1979. A Non-Parametric Approach to the Change-Point Problem. Applied Statistics 28, 126. https://doi.org/10.2307/2346729

Pradhan, B., 2013. A comparative study on the predictive ability of the decision tree, support vector machine and neuro-fuzzy models in landslide susceptibility mapping using GIS. Computers \& Geosciences 51, 350-365. https://doi.org/10.1016/j.cageo.2012.08.023

Qi, H., Xiao, S., Shi, R., Ward, M.P., Chen, Y., Tu, W., Su, Q., Wang, W., Wang, X., Zhang, Z., 2020. COVID-19 transmission in Mainland China is associated with temperature and humidity: A time-series analysis. Science of The Total Environment 728, 138778. https://doi.org/10.1016/j.scitotenv.2020.138778

Rocklöv, J., Sjödin, H., 2020. High population densities catalyse the spread of COVID-19. J Travel Med 27. https://doi.org/10.1093/jtm/taaa038

Sen, P.K., 1968. Estimates of the Regression Coefficient Based on Kendall's Tau. Journal of the American Statistical Association 63, 1379-1389. https://doi.org/10.1080/01621459.1968.10480934

Shi, P., Dong, Y., Yan, H., Zhao, C., Li, X., Liu, W., He, M., Tang, S., Xi, S., 2020. Impact of temperature on the dynamics of the COVID-19 outbreak in China. Science of The Total Environment 728, 138890. https://doi.org/10.1016/j.scitotenv.2020.138890 
medRxiv preprint doi: https://doi.org/10.1101/2020.06.15.20131490; this version posted June 17, 2020. The copyright holder for this preprint (which was not certified by peer review) is the author/funder, who has granted medRxiv a license to display the preprint in perpetuity.

All rights reserved. No reuse allowed without permission.

Song, S., Zhan, Z., Long, Z., Zhang, J., Yao, L., 2011. Comparative study of SVM methods combined with voxel selection for object category classification on fMRI data. PLoS ONE 6, e17191. https://doi.org/10.1371/journal.pone.0017191

Sooryanarain, H., Elankumaran, S., 2015. Environmental Role in Influenza Virus Outbreaks. Annual Review of Animal Biosciences 3, 347-373. https://doi.org/10.1146/annurevanimal-022114-111017

Tamerius, J.D., Shaman, J., Alonso, W.J., Bloom-Feshbach, K., Uejio, C.K., Comrie, A., Viboud, C., 2013. Environmental Predictors of Seasonal Influenza Epidemics across Temperate and Tropical Climates. PLOS Pathogens 9, e1003194. https://doi.org/10.1371/journal.ppat.1003194

Tan, J., Mu, L., Huang, J., Yu, S., Chen, B., Yin, J., 2005. An initial investigation of the association between the SARS outbreak and weather: with the view of the environmental temperature and its variation. J Epidemiol Community Health 59, 186192. https://doi.org/10.1136/jech.2004.020180

Tehrany, M.S., Pradhan, B., Jebur, M.N., 2014. Flood susceptibility mapping using a novel ensemble weights-of-evidence and support vector machine models in GIS. Journal of Hydrology 512, 332-343. https://doi.org/10.1016/j.jhydrol.2014.03.008

Tehrany, M.S., Pradhan, B., Mansor, S., Ahmad, N., 2015. Flood susceptibility assessment using GIS-based support vector machine model with different kernel types. CATENA 125, 91-101. https://doi.org/10.1016/j.catena.2014.10.017

Tien Bui, D., Pradhan, B., Lofman, O., Revhaug, I., 2012. Landslide Susceptibility Assessment in Vietnam Using Support Vector Machines, Decision Tree, and Naïve Bayes Models [WWW Document]. Mathematical Problems in Engineering. https://doi.org/10.1155/2012/974638 
medRxiv preprint doi: https://doi.org/10.1101/2020.06.15.20131490; this version posted June 17, 2020. The copyright holder for this preprint (which was not certified by peer review) is the author/funder, who has granted medRxiv a license to display the preprint in perpetuity.

All rights reserved. No reuse allowed without permission.

429 Tosepu, R., Gunawan, J., Effendy, D.S., Ahmad, L.O.A.I., Lestari, H., Bahar, H., Asfian, P.,

430

431

432

433

434

435

436

437

438 2020. Correlation between weather and Covid-19 pandemic in Jakarta, Indonesia. Science of The Total Environment 725, 138436. https://doi.org/10.1016/j.scitotenv.2020.138436

Unkel, S., Farrington, C.P., Garthwaite, P.H., Robertson, C., Andrews, N., 2012. Statistical methods for the prospective detection of infectious disease outbreaks: a review. Journal of the Royal Statistical Society. Series A (Statistics in Society) 175, 49-82.

Wang, C., Horby, P.W., Hayden, F.G., Gao, G.F., 2020a. A novel coronavirus outbreak of global health concern. The Lancet 395, 470-473. https://doi.org/10.1016/S01406736(20)30185-9

Wang, M., Jiang, A., Gong, L., Luo, L., Guo, W., Li, Chuyi, Zheng, J., Li, Chaoyong, Yang, B., Zeng, J., Chen, Y., Zheng, K., Li, H., 2020b. Temperature significant change COVID-19 Transmission in 429 cities. medRxiv 2020.02.22.20025791. https://doi.org/10.1101/2020.02.22.20025791

Wang, Y., Wang, Yuyi, Chen, Y., Qin, Q., 2020c. Unique epidemiological and clinical features of the emerging 2019 novel coronavirus pneumonia (COVID-19) implicate special control measures. Journal of Medical Virology 92, 568-576. https://doi.org/10.1002/jmv.25748

Wijngaard, J.B., Tank, A.M.G.K., Können, G.P., 2003. Homogeneity of 20th century European daily temperature and precipitation series. International Journal of Climatology 23, 679-692. https://doi.org/10.1002/joc.906

Wu, Z., McGoogan, J.M., 2020. Characteristics of and Important Lessons From the Coronavirus Disease 2019 (COVID-19) Outbreak in China: Summary of a Report of 72314 Cases From the Chinese Center for Disease Control and Prevention. JAMA 323, 1239. https://doi.org/10.1001/jama.2020.2648 
medRxiv preprint doi: https://doi.org/10.1101/2020.06.15.20131490; this version posted June 17, 2020. The copyright holder for this preprint (which was not certified by peer review) is the author/funder, who has granted medRxiv a license to display the preprint in perpetuity.

454 Wurtzer, S., Marechal, V., Mouchel, J.-M., Maday, Y., Teyssou, R., Richard, E., Almayrac,

455

456

457

458

459

460

461

462

463

464
J.L., Moulin, L., 2020. Evaluation of lockdown impact on SARS-CoV-2 dynamics through viral genome quantification in Paris wastewaters. medRxiv 2020.04.12.20062679. https://doi.org/10.1101/2020.04.12.20062679

Xie, J., Zhu, Y., 2020. Association between ambient temperature and COVID-19 infection in 122 cities from China. Science of The Total Environment 724, 138201. https://doi.org/10.1016/j.scitotenv.2020.138201

Yao, X., Tham, L.G., Dai, F.C., 2008. Landslide susceptibility mapping based on Support Vector Machine: A case study on natural slopes of Hong Kong, China. Geomorphology 101, 572-582. https://doi.org/10.1016/j.geomorph.2008.02.011

Yuan, J., Yun, H., Lan, W., Wang, W., Sullivan, S.G., Jia, S., Bittles, A.H., 2006. A climatologic investigation of the SARS-CoV outbreak in Beijing, China. Am J Infect Control 34, 234-236. https://doi.org/10.1016/j.ajic.2005.12.006

Zhu, N., Zhang, D., Wang, W., Li, X., Yang, B., Song, J., Zhao, X., Huang, B., Shi, W., Lu, R., Niu, P., Zhan, F., Ma, X., Wang, D., Xu, W., Wu, G., Gao, G.F., Tan, W., 2020. A Novel Coronavirus from Patients with Pneumonia in China, 2019. N Engl J Med 382, 727-733. https://doi.org/10.1056/NEJMoa2001017

Zu, Z.Y., Jiang, M.D., Xu, P.P., Chen, W., Ni, Q.Q., Lu, G.M., Zhang, L.J., 2020. Coronavirus Disease 2019 (COVID-19): A Perspective from China. Radiology 200490. https://doi.org/10.1148/radiol.2020200490 
medRxiv preprint doi: https://doi.org/10.1101/2020.06.15.20131490; this version posted June 17, 2020. The copyright holder for this preprint (which was not certified by peer review) is the author/funder, who has granted medRxiv a license to display the preprint in perpetuity. All rights reserved. No reuse allowed without permission.

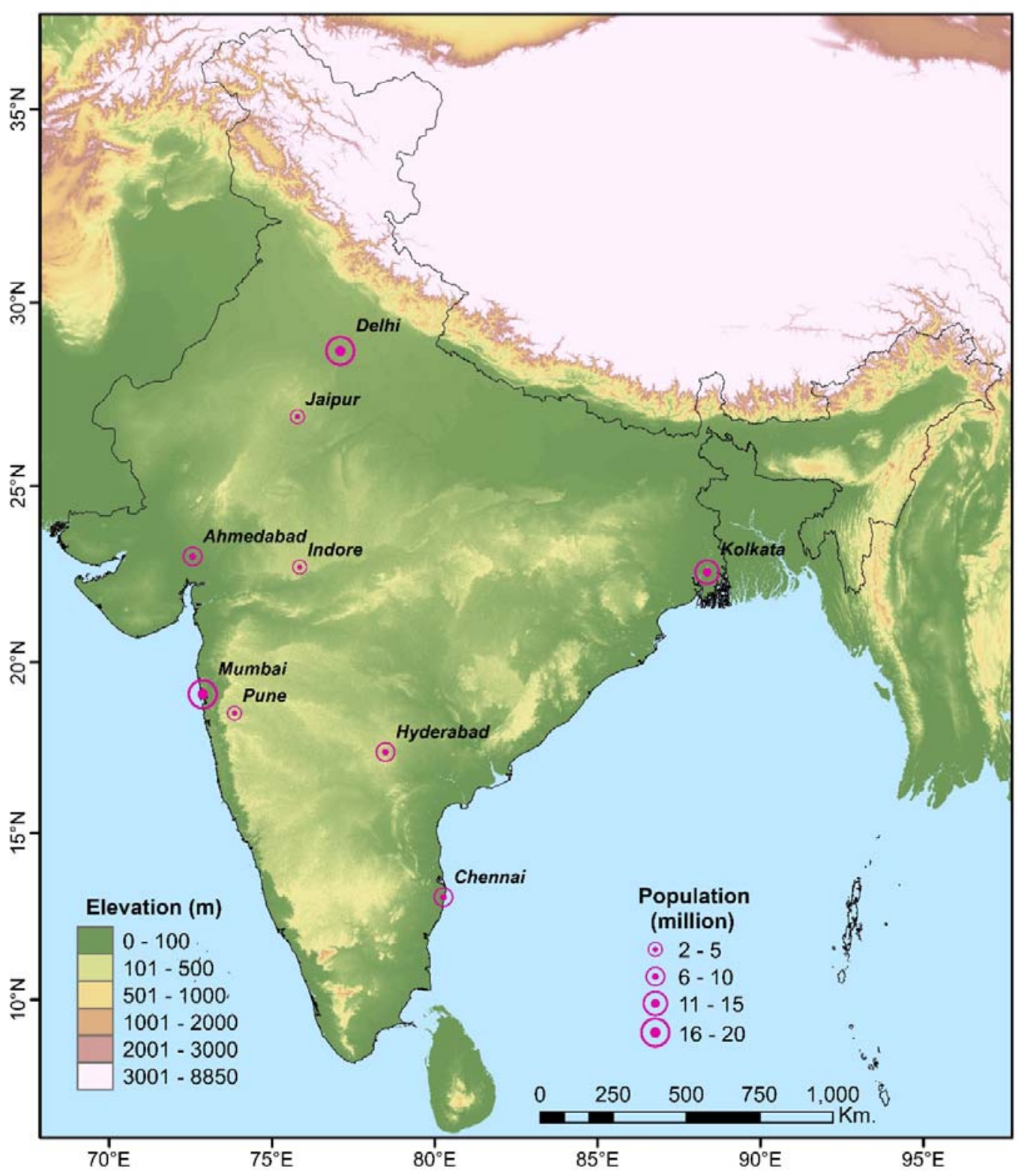

480 Fig. 1 Location of the selected cities in India along with the total population of those cities. 


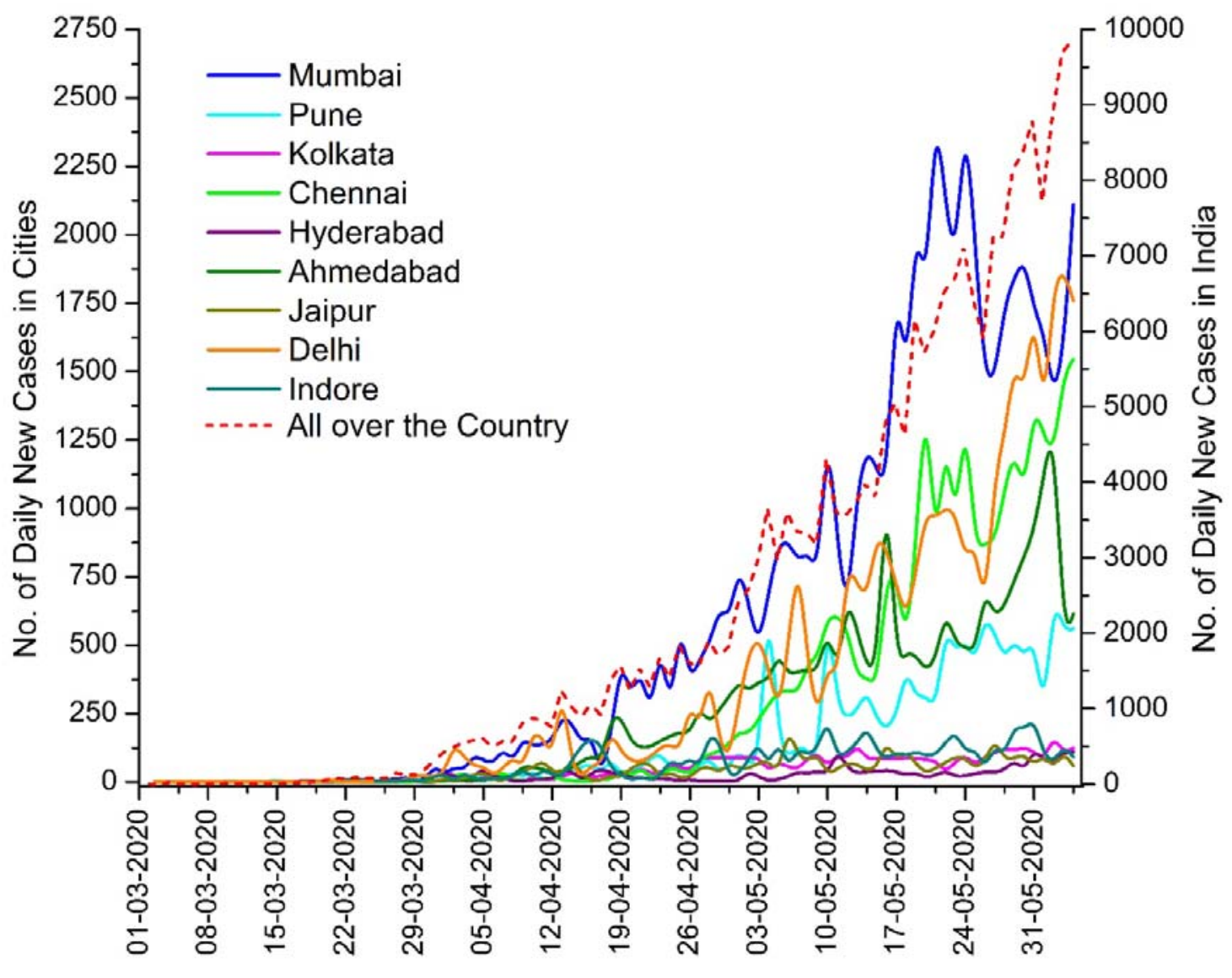

488 Fig. 2 Trend of daily confirmed cases over selected cities and all-over the country. 
medRxiv preprint doi: https://doi.org/10.1101/2020.06.15.20131490; this version posted June 17, 2020. The copyright holder for this preprint (which was not certified by peer review) is the author/funder, who has granted medRxiv a license to display the preprint in perpetuity. All rights reserved. No reuse allowed without permission.

491
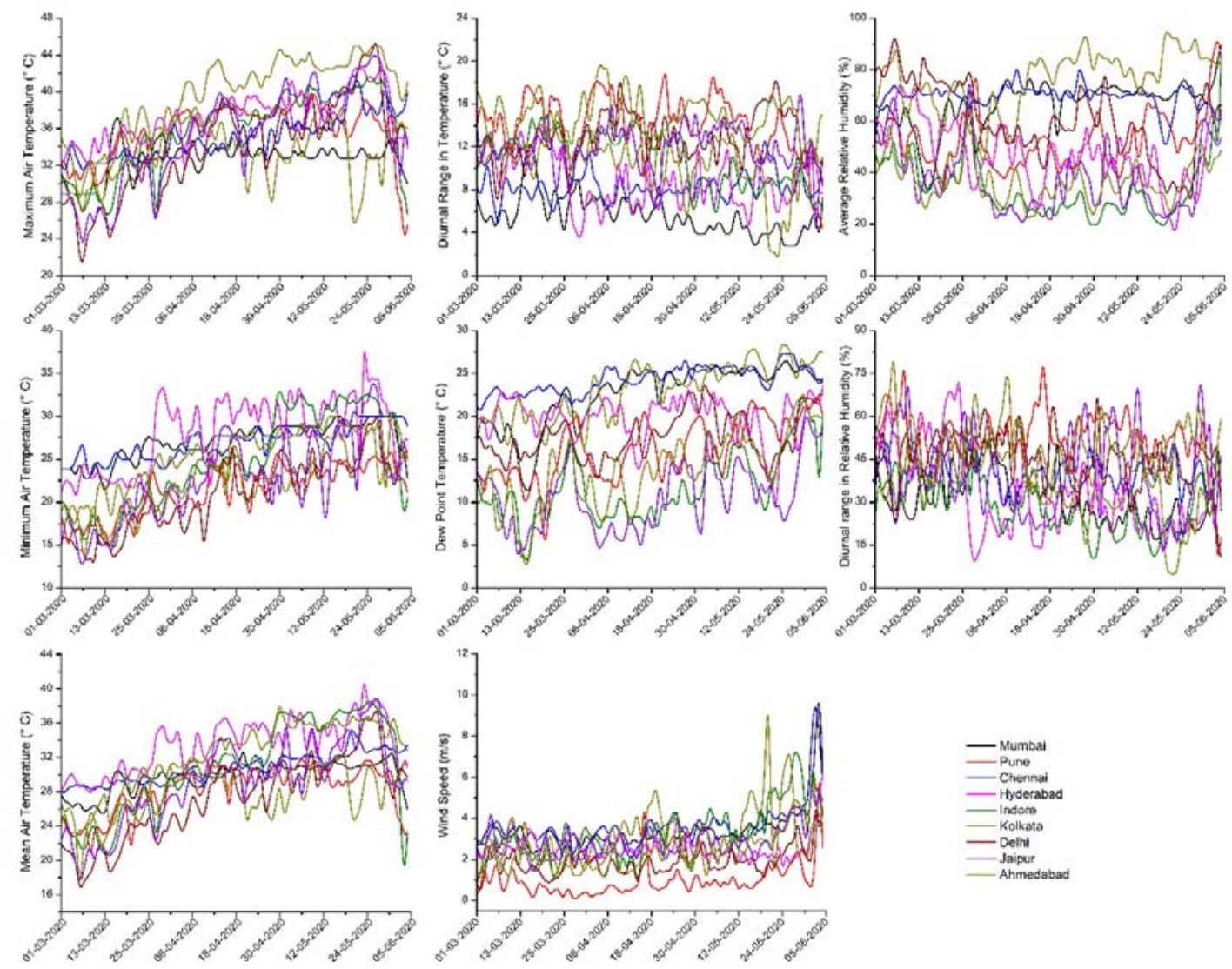

492

Fig. 3 Pattern of Daily Weather over the selected cities in India.

493

494

495

496

497

498

499

500 
medRxiv preprint doi: https://doi.org/10.1101/2020.06.15.20131490; this version posted June 17, 2020. The copyright holder for this preprint (which was not certified by peer review) is the author/funder, who has granted medRxiv a license to display the preprint in perpetuity. All rights reserved. No reuse allowed without permission.

501

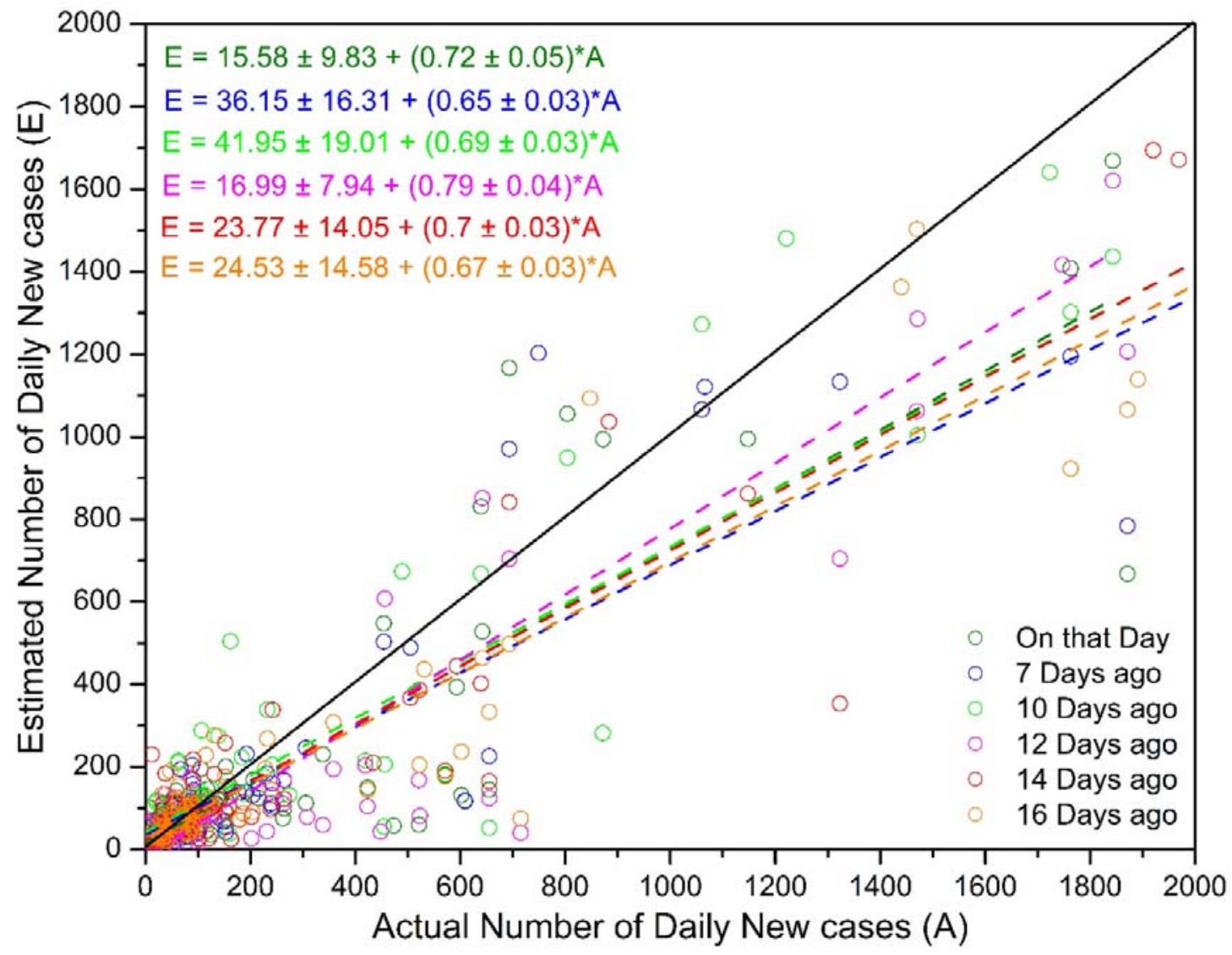

503 Fig. 4 Validation of SVM based regression model for estimating daily transmission. 
medRxiv preprint doi: https://doi.org/10.1101/2020.06.15.20131490; this version posted June 17, 2020. The copyright holder for this preprint (which was not certified by peer review) is the author/funder, who has granted medRxiv a license to display the preprint in perpetuity.

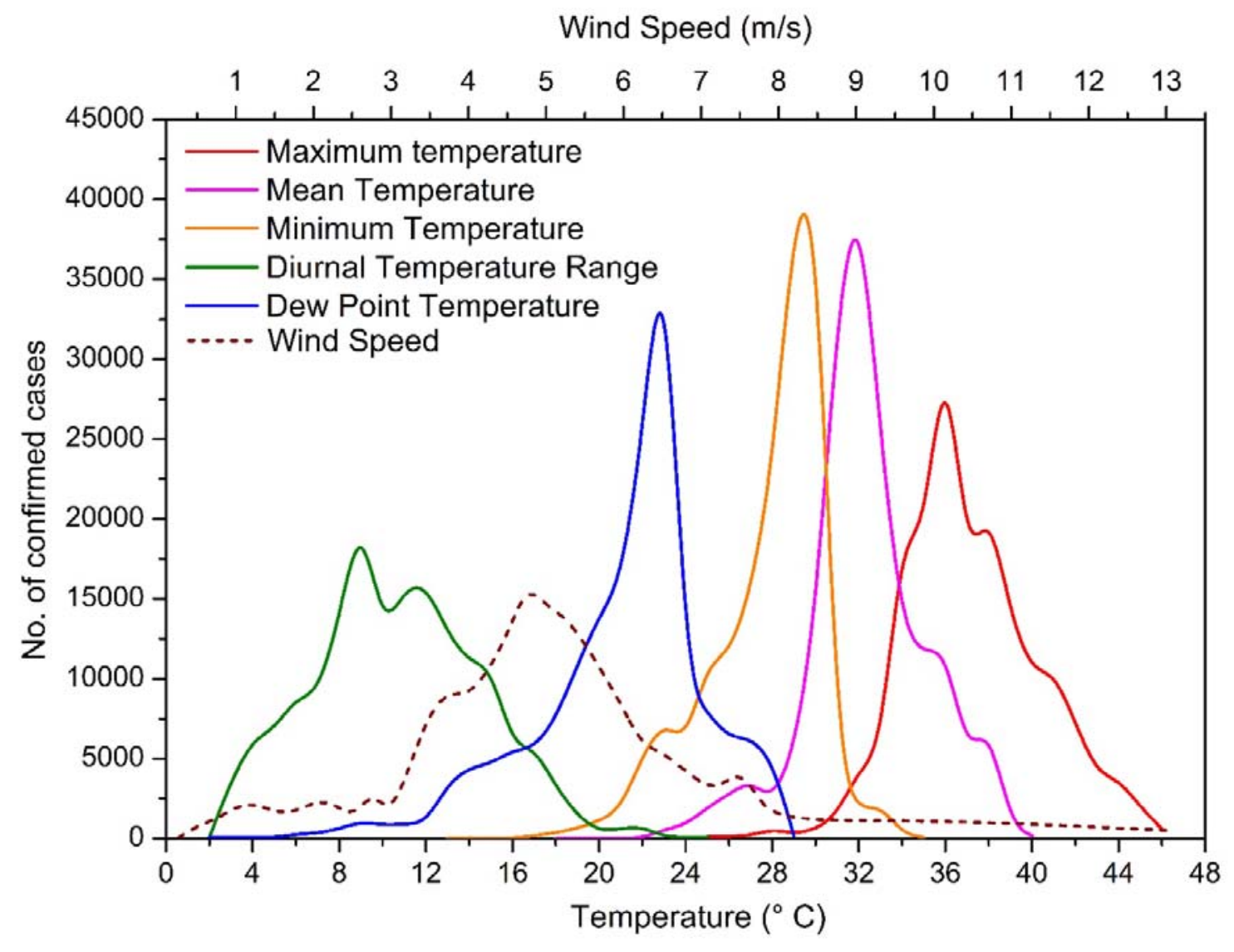

513 Fig. 5 Influence of weather parameters on count of confirmed cases with a lag of 12-16 days. 
medRxiv preprint doi: https://doi.org/10.1101/2020.06.15.20131490; this version posted June 17, 2020. The copyright holder for this preprint (which was not certified by peer review) is the author/funder, who has granted medRxiv a license to display the preprint in perpetuity.

All rights reserved. No reuse allowed without permission.

521 Table 1 Result of Spearman's correlation test

\begin{tabular}{lllllll}
\hline & On that & 7 Days & 10 Days & 12 Days & 14 Days & 16 Days \\
Parameters & Day & ago & ago & ago & ago & ago \\
\hline Maximum Temperature & $0.161^{*}$ & $0.198^{*}$ & $0.231^{*}$ & $0.336^{*}$ & $0.347^{*}$ & $0.272^{*}$ \\
Minimum Temperature & $0.244^{*}$ & $0.285^{*}$ & $0.319^{*}$ & $0.417^{*}$ & $0.436^{*}$ & $0.351^{*}$ \\
Mean Temperature & $0.199^{*}$ & $0.248^{*}$ & $0.287^{*}$ & $0.409^{*}$ & $0.430^{*}$ & $0.337^{*}$ \\
Temperature Range & -0.032 & -0.043 & -0.066 & -0.064 & -0.075 & -0.054 \\
Dew Point Temperature & $0.222^{*}$ & $0.235^{*}$ & $0.261^{*}$ & $0.238^{*}$ & $0.269^{*}$ & $0.238^{*}$ \\
Average Relative Humidity & $0.128^{*}$ & $0.1 *$ & $0.09^{*}$ & 0.002 & 0.008 & 0.034 \\
Humidity Range & -0.016 & -0.024 & -0.056 & $-0.13^{*}$ & $-0.149^{*}$ & $-0.095^{*}$ \\
Wind Speed & & & & & & \\
& $0.108^{*}$ & $0.133^{*}$ & $0.163^{*}$ & $0.221^{*}$ & $0.255^{*}$ & $0.193^{*}$ \\
\hline
\end{tabular}

*Significant at 0.05 significance level.

523

524 Table 2 Result of Validation of SVM based regression for estimating daily transmission.

\begin{tabular}{llll}
\hline & $\mathrm{R}^{2}$ & RMSE & $\mathrm{MB}$ \\
\hline On that Day & 0.6414 & 199.2929 & -48.1804 \\
7 Days ago & 0.7015 & 202.1743 & -40.0377 \\
10 Days ago & 0.8286 & 223.1949 & -42.0560 \\
12 Days ago & 0.8503 & 186.0126 & -66.9880 \\
14 Days ago & 0.8680 & 178.3891 & -43.6459 \\
16 Days ago & 0.8714 & 202.2428 & -60.0658 \\
\hline
\end{tabular}

525 